\title{
Quantitative and qualitative microbial diversity of the raw cow's milk sold by street trading in Meknes, Morocco
}

\author{
Aziz Bouymajane1, Fouzia Rhazi Filali, Faouzia Benhallam¹, Abdelaziz Ed-dra1, Abdallah El Allaoui', \\ Abdellah Chaiba ${ }^{1}$, Amal Aboulkacem ${ }^{2}$ and Mohamed Ait $\mathrm{Hou}^{3}$ \\ ${ }^{1}$ Team of Microbiology and Health, Laboratory of Chemistry-Biology Applied to the Environment, \\ Moulay Ismail University Faculty of Sciences, BP. 11201 Zitoune Meknes, Morocco. \\ ${ }^{2}$ Regional Laboratory of Epidemiological Diagnosis and Environmental Hygiene, Fes-Meknes, Morocco. \\ ${ }^{3}$ Polydisciplinary Faculty of Errachidia, Moulay Ismail University, BP. 512, Boutalamine, Errachidia, Morocco. \\ Email: fouzia.filali@yahoo.fr
}

Received 5 March 2018; Received in revised form 4 December 2018; Accepted 13 June 2019

\begin{abstract}
Aims: Milk is rich of nutrients that are necessary for the growth of various microorganisms. The aim of the present study was to evaluate the microbial quantity and quality of the raw cow's milk sold through street trading in Meknes, Morocco, and to study the variation and seasonal relationship of microbial diversity during the four seasons of the year.

Methodology and results: Raw cow's milk samples were collected randomly between May 2015 and April 2016 from 3 street trading sale points, two popular neighborhoods (station 1 and station 2) and one popular market, and they were analyzed microbiologically. The results showed that the contamination rates of Total Plate Count (TPC), total coliforms, fecal coliforms, lactobacilli, lactococci and yeasts and molds were $8.8 \times 10^{8} \mathrm{CFU} / \mathrm{mL}, 8.9 \times 10^{5} \mathrm{CFU} / \mathrm{mL}, 2 \times 10^{3} \mathrm{CFU} / \mathrm{mL}$, $4.6 \times 10^{8} \mathrm{CFU} / \mathrm{mL}, 7.5 \times 10^{8} \mathrm{CFU} / \mathrm{mL}$ and $4.1 \times 10^{3} \mathrm{CFU} / \mathrm{mL}$, respectively. Moreover, Escherichia coli, Staphylococcus aureus, Clostridium perfringens and Listeria monocytogenes were detected in $66.67 \%(24 / 36), 75 \%(27 / 36), 36.1 \%$ $(13 / 36)$ and $19.44 \%(7 / 36)$, respectively, while Salmonella was not detected in this study.

Conclusion, significance and impact of study: The highest microbiological count in raw milk samples was found in summer, while the lowest was detected in winter $(p<0.005)$. Therefore, the quality of milk marketed in Meknes region of Morocco is deteriorated due to the lack of good hygienic conditions of raw cow's milk sold through street trading.
\end{abstract}

Keywords: Raw cow's milk, street trading, microbiological quality, season

\section{INTRODUCTION}

Milk is the integral product of the total and discontinued milking of a healthy, well-fed and undisturbed dairy female; milk must be collected properly and must not contain colostrum (Pougheon and Goursaud, 2001). It is a nutritive and valuable food product. In many countries, dairy products form a large portion of the daily diet of people, especially infants and children (Koushki et al., 2016). Milk is mainly composed of water, proteins, carbohydrates, lipids, vitamins and minerals (Schechter, 2009) and it is a rich source of nutrients and energy (Koushki et al., 2016). Several microorganisms are responsible for the spoilage of milk and dairy products (lactic acid bacteria) and cause foodborne diseases (Enterobacteriaceae, L. monocytogenes, Staphylococcus aureus, Mycobacterium tuberculosis), the strict anaerobic spore-forming Clostridia, molds and yeast, other Gramnegative pathogens and protozoans (Schaechter, 2009; Paszkiewicz et al., 2015; Koushki et al., 2016; Lan et al.,
2017). However, raw milk microflora contributes greatly to the sensory characteristic and bio-preservation of foods. There are many sources of contamination of milk, including the cow itself, the environment, water, and milking equipments (Lejeune and Rajala-schultz, 2009; Millogo et al., 2009; Griffiths, 2010).

Poor quality of raw milk causes a health threat and economic burden; so many efforts are made to improve its quality (Mallet et al., 2012). During the last decades, the development of food safety measures is applied to ensure safe and qualitative food products by involving Hazard Analysis and Critical Control Points. (HACCP) (Smigic et al., 2012; Schaarschmidt et al., 2016). Worldwide, food-borne illnesses are a major public health problem, with more than 200 diseases caused by improper foods that contain pathogenic bacteria, viruses, parasites or harmful chemicals (WHO, 2015).

In Morocco, food-borne outbreaks are very frequent, occurring in all regions of the country, and more widespread in summer and spring. They are accidental, 
affecting both young people and adults, and are generally nonthreatening although sometimes they are fatal (EdDra et al., 2017a). In 2015, the APPC (Anti-poison and Pharmacovigilance Center) identified 2887 cases of foodborne illnesses in Morocco, from which $60.8 \%$ were collective poisoning (CAPM, 2015). The incriminated products were meat and meat products $(21.7 \%)$, dairy products $(9.2 \%)$ fish and fishery products $(8.7 \%)$ and composite foods (7.0\%) (CAPM, 2015).

In Morocco, the delivering of milk and milk products from the farm to the consumer involves two types of marketing channels (Bouymajane et al., 2018). The first one involves industrial collection centers. The second one is based on the selling of milk by street traders who collect it from the farms and sell it to traditional dairies (Mahlabates), coffee shops and urban households, using motorbikes and vans as means of transport (Hervieu, 2007). It should be noted that the raw milk marketed by street trader does not undergo any microbiological quality control. Nearly, $30 \%$ of the total quantities of milk were intended for cities (Hervieu, 2007).

The aim of the present study was to evaluate the microbial quantity and quality of the raw cow's milk sold through street trading in Meknes, northern central of Morocco.

\section{MATERIALS AND METHODS}

\section{Sample collection}

From May 2015 to April 2016, a total of thirty-six raw cow's milk samples were randomly collected from three selected street trading sale points, two popular neighborhoods (station 1 and station 2) and the souk, located in Meknes city (northern central Morocco). One liter of raw milk was collected aseptically into a sterile container in the cool box kept at $4{ }^{\circ} \mathrm{C}$ and brought to the Laboratory of Microbiology and health of the Faculty of Science of Meknes. The analyses were performed on the same day.

\section{Microbiological analysis}

Twenty-five grams of raw milk was added to $225 \mathrm{~mL}$ of buffered peptone water (Oxoid) and homogenized for 3 $\min$ at 260 rotations per min (rpm), using a Masticator (Stomacher 400 Circulator, Seward). Then, the decimal dilutions were carried out.

Total microbial count, total coliform, fecal coliform, and $E$. coli

The total microbial count was counted after incubation at $37{ }^{\circ} \mathrm{C}$ for 48 h (NF V08-051, 1999) on Plant Count Agar (PCA, Biokar). Total and fecal coliform were carried out on Violet Red Bile Glucose Agar (VRBL, Biokar), after incubation at $30^{\circ} \mathrm{C}$ for $24 \mathrm{~h}$ (ISO 4832, 2006) and $44^{\circ} \mathrm{C}$ (NF V08-060, 2009) respectively. E. coli colonies were confirmed by the indole test (V08-053, 2002).

\section{Staphylococcus spp.}

Staphylococcus spp. were plated out in the Baird Parker medium (BP, Biokar) agar containing $5 \%$ of the egg yolk after incubation at $37{ }^{\circ} \mathrm{C}$ for $48 \mathrm{~h}$ and confirmed by the coagulase test (NF V08-057, 2004).

\section{Anaerobic sulfate-reducing bacteria}

Anaerobic sulfate-reducing bacteria (ASR) were carried out, on Tryptone Cycloserine Sulphite (TCS) agar supplemented with D-cycloserine (Biokar) and incubated at $46{ }^{\circ} \mathrm{C}$ for $24 \mathrm{~h}$ (NM 08.0.125, 2012).

\section{Molds and yeasts}

Molds and yeasts were counted after incubation on Sabouraud dextrose agar with chloramphenicol (Biokar) at $25^{\circ} \mathrm{C}$ for 5 days (ISO 7954,2003 ).

\section{Lactic acid bacteria}

Lactococci and lactobacilli were plated on Rogosa and Sharpe (MRS) agar and M17 agar (Biokar) and incubated at $30^{\circ} \mathrm{C}$ and $37^{\circ} \mathrm{C}$ for $72 \mathrm{~h}$ and $48 \mathrm{~h}$, respectively (ISO/ FDIS 15214, 1998).

\section{Salmonella spp.}

Salmonella spp. were isolated from different samples by using conventional methods and confirmed by Biochemical tests according to the method described previously (Ed-dra et al., 2017b).

\section{L. monocytogenes}

Ten $\mathrm{mL}$ of raw milk samples were enriched on $90 \mathrm{~mL}$ of half Fraser Broth (Biokar), homogenized and incubated at $30{ }^{\circ} \mathrm{C}$ for $24 \mathrm{~h}$. Then, $0.1 \mathrm{~mL}$ of enrichment broth was inoculated onto $9 \mathrm{~mL}$ of Fraser Broth (Biokar) and incubated at $37{ }^{\circ} \mathrm{C}$ for $48 \mathrm{~h}$. Approximately $10 \mu \mathrm{L}$ were streaked onto Polymyxin Acriflavine Lithium chloride Ceftazidime Aesculin Mannitol (PALCAM) agar plates (Biokar) and incubated at $37^{\circ} \mathrm{C}$ for $24-48 \mathrm{~h}$. Presumptive L. monocytogenes were purified on Trypticase Soy Agar (TSA, Biokar) and confirmed using Gram staining, catalase, oxidase, hemolysis test, Christie Atkins and Munch-Peterson (CAMP) test and API listeria (NM 08.0.110, 2004).

\section{Statistical analysis}

Simple descriptive statistical analyses were performed to evaluate the parameters of the microbial quantity and quality. Furthermore, to evaluate the existence of statistical differences between the parameters evaluated by season and site. Analysis of variance (ANOVA) was carried out using SPSS software (SPSS version 20, IBM Corp, Armonk, NY, USA). A $p$-value $<0.05$ was considered statistically significant. 


\section{RESULTS AND DISCUSSION}

The findings of this study, concerning the microbiological analysis of raw cow's milk samples taken randomly from the different points of sale located in two popular neighborhoods and the popular market of the city of Meknes, are reported in Table 1.

Table 1: Microbial load of raw milk collected from street trading in Meknes city of Morocco.

\begin{tabular}{|c|c|c|c|c|}
\hline & $\begin{array}{c}\text { Mean } \\
\text { (CFU/ } \\
\text { mL) }\end{array}$ & $\begin{array}{c}\text { Min } \\
(\mathrm{CFU} / \\
\mathrm{mL})\end{array}$ & $\begin{array}{c}\text { Max } \\
\text { (CFU/ } \\
\text { mL) }\end{array}$ & $\%$ \\
\hline Total plate count & $8.8 \times 10^{8}$ & $2 \times 10^{5}$ & $9.6 \times 10^{9}$ & - \\
\hline Total coliforms & $8.9 \times 10^{5}$ & 25 & $5.8 \times 10^{6}$ & - \\
\hline Fecal coliforms & $2 \times 10^{3}$ & 10 & $9.2 \times 10^{3}$ & - \\
\hline Yeasts and molds & 11 & $4.4 \times 10^{4}$ & $4.1 \times 10^{3}$ & - \\
\hline Lactobacilli & $4.6 \times 10^{8}$ & $5 \times 10^{4}$ & $8.1 \times 10^{8}$ & - \\
\hline Lacbacocci & $7.5 \times 10^{8}$ & $5.5 \times 10^{4}$ & $8.8 \times 10^{8}$ & - \\
\hline C. perfringens & - & - & - & 36.1 \\
\hline E. coli & - & - & - & 66.67 \\
\hline S. aureus & - & - & - & 75 \\
\hline L. monocytogenes & - & - & - & 19.44 \\
\hline Salmonella spp. & - & - & - & 0 \\
\hline
\end{tabular}

\section{Total plate count}

Our study showed a high prevalence of total plate count (TPC) of $8.8 \times 10^{8} \mathrm{CFU} / \mathrm{mL}$ (Table 1), which is much more noticeable in summer than in winter (Table 2). This means that it is higher than the limit set by Moroccan standards $\left(3 \times 10^{5} \mathrm{CFU} / \mathrm{mL}\right)$ (Ministry of Agriculture, 2004). Several factors may be involved such as the physical state of the cow, unhygienic milking equipment, microbiological quality of water and milk storage conditions. The TPC results found ranged from $2 \times 10^{5}$ to $9.6 \times 10^{9} \mathrm{CFU} / \mathrm{mL}$. In our study, the TPC load is higher than that found previously in dairy products in Rabat city of Morocco $\left(6.9 \times 10^{8} \mathrm{CFU} / \mathrm{mL}\right)$ (Hadrya et al., 2012), in Malaysia $\left(12 \times 10^{6} \mathrm{CFU} / \mathrm{mL}\right)$ (Fook et al., 2004), in China $\left(2 \times 10^{6} \mathrm{CFU} / \mathrm{mL}\right)$ (Lan et al., 2017), and Burlington ( $<10^{5} \mathrm{CFU} / \mathrm{mL}$ ) (D'Amico and Donnelly, 2010). In USA the TPC varies between $2.7 \times 10^{4} \mathrm{CFU} / \mathrm{mL}$ and $2.1 \times 10^{8} \mathrm{CFU} / \mathrm{mL}$ (Brooks et al., 2012). However, the milking parlor, the milking process, milking machines, milk pipelines, transport tankers, and cooling units should be cleaned to improve the quality of milk (Özer, B. and Yaman H., 2014).

\section{Total coliforms and E. coli}

The average counts of total coliforms were $8.9 \times 10^{5}$ $\mathrm{CFU} / \mathrm{mL}$ (Table 1). This value was higher than that reported in Malaysia (17 CFU/mL) (Fook et al., 2004) and USA (between $50 \mathrm{CFU} / \mathrm{mL}$ and $1.7 \times 10^{3} \mathrm{CFU} / \mathrm{mL}$ ) (Brooks et al., 2012), and lower than that reported in Sudan (between $1.2 \times 10^{9}$ and $1.5 \times 10^{10} \mathrm{CFU} / \mathrm{mL}$ ) (Ibtissam and Mahboba, 2007). On the other hand, E. coli was detected in $66.67 \%$ of samples (Table 1), which was similar to that found in Malaysia 64.5\% (Fook et al., 2004) and higher than that reported in China 45\% (Lan et al., 2017). However, the presence of $E$. coli and coliform in food products is considered as an indicator of fecal contamination (Fook et al., 2004; Ghafir et al., 2008). It should be noted that the total coliforms and $E$. coli levels detected in samples taken during summer and autumn are higher than those of winter and spring (Table 2).

\section{Staphylococcus aureus}

Staphylococcus aureus is responsible for mastitis in dairy herds, involving the inflammation of the mammary glands and sporadic shedding of $S$. aureus cells into the raw milk (Barkema et al., 2006); it is recognized that $S$. aureus produces pathogenic enterotoxins which cause human diseases (Hill et al., 2012). In our study, the prevalence of $S$. aureus was $75 \%$ (Table 1) and the frequency of its isolation from the taken samples was high (Table 1). This value is greater than that found in China (45\%) (Lan et al., 2017 ) and in another study in Morocco (30\%) (Ismaili et al., 2016).

\section{Salmonella spp.}

The results of our study showed the absence of Salmonella in the analyzed samples (Table 1). These results are similar to those reported in raw milk from Switzerland, Finland, and Belgium (Piret et al., 2015). Nevertheless, Salmonella has been detected in raw milk collected from many countries, such as China (1.25\%) (Lan et al., 2017), Italy (0.3\%) (Piret et al., 2015) and Canada (6\%) (Griffiths, 2010).

\section{Listeria monocytogenes}

Listeria monocytogenes can grow under different conditions such as a wide range of $\mathrm{pH}$, refrigerated temperatures, water activity, and high salinity; it is responsible for listeriosis (Yoon et al., 2016). Our results showed the presence of $L$. monocytogenes in $19.44 \%$ of analyzed samples (Table 1). However, it was detected in other studies with a lower contamination rate, in Europe from $2.2 \%$ to $10.2 \%$ (Wendie et al., 2013), New Zeland $0.68 \%$ (Hill et al., 2012), Malaysia 4.4\% (Fook et al., 2004), China 1.8\% (Lan et al., 2017), Finland 5.5\% (Lan et al., 2017), and Poland $2.58 \%$ (Paszkiewicz et al., 2015). In addition, the incidence of $L$. monocytogenes in winter and spring is higher than that of autumn and Summer (Table 2), this effect may be explained by the variation of factors influencing the growth of $L$. monocytogenes such as a wide range of temperature (0.15 to $\left.45^{\circ} \mathrm{C}\right), \mathrm{pH}$ (4.3 to 9.4), high water activities $(>0.92)$ and salt $(10 \% \mathrm{NaCl})$ (Liu, 2008). 
Malays. J. Microbiol. Vol 15(6) 2019, pp. 425-431 DOI: http://dx.doi.org/10.21161/mjm.180079

Table 2: Bacteriological quality of raw cow's milk collected from street trading depending of the season (CFU/mL), statistically

\begin{tabular}{|c|c|c|c|c|c|c|c|c|c|c|c|c|c|}
\hline & & \multicolumn{3}{|c|}{ Total plate count } & \multicolumn{3}{|c|}{ Total coliforms } & \multicolumn{3}{|c|}{ Fecal coliforms } & \multicolumn{3}{|c|}{ Clostridium perfringens } \\
\hline & & Min & Max & Mean & Min & Max & Mean & Min & Max & Mean & Min & Max & Mean \\
\hline \multirow{3}{*}{ 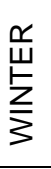 } & Station 1 & $2.6 \times 10^{5}$ & $1.6 \times 10^{6}$ & $7.3 \times 10^{5}$ & 25 & $6.0 \times 10^{3}$ & $2.0 \times 10^{3}$ & 12 & 50 & 34 & 0 & 0 & 0 \\
\hline & Station 2 & $2.3 \times 10^{5}$ & $2.0 \times 10^{6}$ & $8.4 \times 10^{5}$ & 30 & $5.6 \times 10^{3}$ & $2.0 \times 10^{3}$ & 10 & 70 & 33 & 0 & 0 & 0 \\
\hline & $\begin{array}{l}\text { Popular } \\
\text { market }\end{array}$ & $3.0 \times 10^{5}$ & $3.0 \times 10^{6}$ & $1.3 \times 10^{6}$ & 40 & $7.4 \times 10^{3}$ & $2.6 \times 10^{3}$ & 14 & $3.0 \times 10^{2}$ & $1.3 \times 10^{2}$ & 0 & 0 & 0 \\
\hline \multirow{3}{*}{ 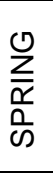 } & Station 1 & $3.1 \times 10^{5}$ & $9.2 \times 10^{6}$ & $3.8 \times 10^{6}$ & $2.8 \times 10^{2}$ & $5.5 \times 10^{4}$ & $2.0 \times 10^{4}$ & 50 & $4.1 \times 10^{2}$ & $2.1 \times 10^{2}$ & 0 & 0 & 0 \\
\hline & Station 2 & $2.0 \times 10^{5}$ & $7.8 \times 10^{6}$ & $4.0 \times 10^{6}$ & $2.3 \times 10^{2}$ & $6.3 \times 10^{4}$ & $2.2 \times 10^{4}$ & 30 & $2.4 \times 10^{2}$ & $1.4 \times 10^{2}$ & 0 & 40 & 13.3 \\
\hline & $\begin{array}{c}\text { Popular } \\
\text { market }\end{array}$ & $5.0 \times 10^{5}$ & $8.0 \times 10^{6}$ & $4.0 \times 10^{6}$ & $3.6 \times 10^{2}$ & $2.0 \times 10^{5}$ & $6.8 \times 10^{4}$ & 40 & $8.0 \times 10^{2}$ & $4.6 \times 10^{2}$ & 0 & 0 & 0 \\
\hline \multirow{3}{*}{ 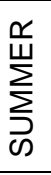 } & Station 1 & $6.0 \times 10^{7}$ & $9.0 \times 10^{9}$ & $3.5 \times 10^{9}$ & $5.5 \times 10^{5}$ & $4.8 \times 10^{6}$ & $2.1 \times 10^{6}$ & $5.5 \times 10^{2}$ & $9.0 \times 10^{3}$ & $6.0 \times 10^{3}$ & 50 & 70 & 61.6 \\
\hline & Station 2 & $5.5 \times 10^{7}$ & $8.7 \times 10^{9}$ & $3.2 \times 10^{9}$ & $4.0 \times 10^{5}$ & $4.2 \times 10^{6}$ & $1.7 \times 10^{6}$ & $5.4 \times 10^{2}$ & $8.8 \times 10^{3}$ & $5.6 \times 10^{3}$ & 50 & 68 & 61 \\
\hline & $\begin{array}{c}\text { Popular } \\
\text { market }\end{array}$ & $8.0 \times 10^{7}$ & $9.6 \times 10^{9}$ & $3.2 \times 10^{9}$ & $6.6 \times 10^{5}$ & $5.6 \times 10^{6}$ & $2.3 \times 10^{6}$ & $6.3 \times 10^{2}$ & $9.2 \times 10^{3}$ & $6.0 \times 10^{3}$ & 45 & 67 & 57.3 \\
\hline \multirow{3}{*}{$\sum_{\substack{2 \\
\frac{2}{2}}}$} & Station 1 & $7.0 \times 10^{6}$ & $1.6 \times 10^{8}$ & $2.1 \times 10^{8}$ & $6.7 \times 10^{4}$ & $4.0 \times 10^{6}$ & $1.5 \times 10^{6}$ & $1.1 \times 10^{2}$ & $3.0 \times 10^{3}$ & $1.1 \times 10^{3}$ & 0 & 30 & 10 \\
\hline & Station 2 & $9.0 \times 10^{6}$ & $5.0 \times 10^{8}$ & $1.9 \times 10^{8}$ & $5.1 \times 10^{4}$ & $1.5 \times 10^{6}$ & $7.3 \times 10^{5}$ & $1.5 \times 10^{2}$ & $1.5 \times 10^{3}$ & $6.2 \times 10^{2}$ & 0 & 20 & 6.6 \\
\hline & $\begin{array}{c}\text { Popular } \\
\text { market }\end{array}$ & $8.0 \times 10^{6}$ & $6.2 \times 10^{8}$ & $1.9 \times 10^{8}$ & $9.0 \times 10^{4}$ & $5.8 \times 10^{6}$ & $2.2 \times 10^{6}$ & $7.0 \times 10^{2}$ & $8.6 \times 10^{3}$ & $3.4 \times 10^{3}$ & 0 & 25 & 8.3 \\
\hline
\end{tabular}


Table 3: Prevalence of lactic acid bacteria, yeast and molds in raw milk collected from street trading depending of the season $(C F U / m L), P<0.05$.

\begin{tabular}{|c|c|c|c|c|c|c|c|c|c|c|}
\hline & & \multicolumn{3}{|c|}{ Yeasts and molds } & \multicolumn{3}{|c|}{ Lactococci } & \multicolumn{3}{|c|}{ Lactobacilli } \\
\hline & & Min & Max & Mean & Min & Max & Mean & Min & Max & Mean \\
\hline \multirow{3}{*}{ 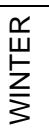 } & Station 1 & 11 & 33 & 24.3 & $6.2 \times 10^{4}$ & $3.0 \times 10^{5}$ & $1.9 \times 10^{5}$ & $2.5 \times 10^{5}$ & $6.0 \times 10^{5}$ & $1.9 \times 10^{5}$ \\
\hline & Station 2 & 12 & $3.2 \times 10^{3}$ & $1.2 \times 10^{3}$ & $5.0 \times 10^{4}$ & $5.0 \times 10^{5}$ & $2.0 \times 10^{5}$ & $5.0 \times 10^{4}$ & $5.0 \times 10^{5}$ & $2.0 \times 10^{5}$ \\
\hline & Popular market & 15 & 24 & 20.6 & $2.5 \times 10^{5}$ & $6.0 \times 10^{5}$ & $4.5 \times 10^{5}$ & $2.5 \times 10^{5}$ & $6.0 \times 10^{5}$ & $4.5 \times 10^{5}$ \\
\hline \multirow{3}{*}{$\begin{array}{l}\frac{N}{z} \\
\frac{z}{\alpha} \\
\text { c) }\end{array}$} & Station 1 & $2.5 \times 10^{3}$ & 70 & 44.33 & $5.6 \times 10^{4}$ & $8.5 \times 10^{6}$ & $3.0 \times 10^{6}$ & $7.4 \times 10^{4}$ & $8.0 \times 10^{5}$ & $3.0 \times 10^{6}$ \\
\hline & Station 2 & 30 & $4 \times 10^{3}$ & $1.7 \times 10^{3}$ & $5.8 \times 10^{4}$ & $7.0 \times 10^{6}$ & $2.5 \times 10^{6}$ & $5.8 \times 10^{4}$ & $7.0 \times 10^{6}$ & $2.5 \times 10^{6}$ \\
\hline & Popular market & 20 & $3 \times 10^{3}$ & $1.26 \times 10^{3}$ & $7.4 \times 10^{4}$ & $8.0 \times 10^{5}$ & $5.5 \times 10^{5}$ & $7.4 \times 10^{4}$ & $8.0 \times 10^{5}$ & $5.5 \times 10^{5}$ \\
\hline \multirow{3}{*}{ 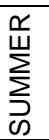 } & Station 1 & $7.7 \times 10^{3}$ & $3.3 \times 10^{4}$ & $1.2 \times 10^{3}$ & $2.5 \times 10^{7}$ & $8.1 \times 10^{10}$ & $2.7 \times 10^{10}$ & $2.6 \times 10^{7}$ & $7.7 \times 10^{9}$ & $2.7 \times 10^{10}$ \\
\hline & Station 2 & $7.4 \times 10^{3}$ & $3.2 \times 10^{4}$ & $1.2 \times 10^{4}$ & $1.5 \times 10^{7}$ & $7.5 \times 10^{10}$ & $2.5 \times 10^{10}$ & $1.5 \times 10^{7}$ & $7.5 \times 10^{10}$ & $2.5 \times 10^{10}$ \\
\hline & Popular market & $8.0 \times 10^{2}$ & $4.4 \times 10^{3}$ & $1.6 \times 10^{4}$ & $4.2 \times 10^{9}$ & $2.6 \times 10^{7}$ & $2.7 \times 10^{9}$ & $2.6 \times 10^{7}$ & $7.7 \times 10^{9}$ & $2.7 \times 10^{9}$ \\
\hline \multirow{3}{*}{ 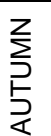 } & Station 1 & $3 \times 10^{3}$ & $4.5 \times 10^{3}$ & $3.8 \times 10^{4}$ & $5.4 \times 10^{6}$ & $8.0 \times 10^{7}$ & $3.8 \times 10^{7}$ & $1.0 \times 10^{6}$ & $6.4 \times 10^{7}$ & $3.8 \times 10^{7}$ \\
\hline & Station 2 & $2 \times 10^{3}$ & $3 \times 10^{3}$ & $2.5 \times 10^{4}$ & $3.6 \times 10^{6}$ & $7.0 \times 10^{7}$ & $3.3 \times 10^{7}$ & $3.6 \times 10^{6}$ & $7.0 \times 10^{7}$ & $3.3 \times 10^{7}$ \\
\hline & Popular market & $4 \times 10^{3}$ & $6 \times 10^{3}$ & $5.0 \times 10^{3}$ & $3.3 \times 10^{7}$ & $1.0 \times 10^{6}$ & $3.8 \times 10^{7}$ & $1.0 \times 10^{6}$ & $6.4 \times 10^{7}$ & $3.8 \times 10^{7}$ \\
\hline
\end{tabular}

\section{Clostridium perfringens}

Clostridium perfringens is a Gram-positive, sporulating anaerobic bacterium responsible for a wide spectrum of diseases in humans and animals (Mcclane, 2001; Ed-Dra et al., 2017c). In this study, the percentage of contamination by $C$. perfringens was $36.1 \%$ (Table 1), with a high frequency in summer and autumn (Table 2). This result is higher than that found in Egypt (20\%) (Rowayda et al., 2015) and in India (10\%) (Gurmu et al., 2013).

\section{Lactococci, lactobacilli, yeasts, and molds}

Lactic acid bacteria improve the diversity of gut microbiota, and its metabolic activities promote human and animal health and/or prevent diseases (Umu et al., 2017). In this study, the means of lactococci and lactobacilli detected in raw cow's milk were $7.5 \times 10^{8}$ $\mathrm{CFU} / \mathrm{mL}$ and $4.6 \times 10^{8} \mathrm{CFU} / \mathrm{mL}$ respectively (Table 1 ). This value is higher than that found beforehand in the camel milk in the south of Morocco (lactococci: $4.25 \times 10^{7}$ $\mathrm{CFU} / \mathrm{mL}$; lactobacilli: $3.55 \times 107 \mathrm{CFU} / \mathrm{mL}$ ) (Alaoui Ismaili et al., 2016). Molds and Yeasts were found at average levels of $4.1 \times 10^{3} \mathrm{CFU} / \mathrm{mL}$, this result is lower than that found previously in Morocco (from $3.13 \times 10^{6} \mathrm{CFU} / \mathrm{mL}$ to $1.60 \times 10^{5} \mathrm{CFU} / \mathrm{mL}$ (Maha et al., 2016). It is worth noting that the highest prevalence of molds and yeasts, lactococci and lactobacilli (Table 3) was recorded during summer and autumn and the lowest in winter and spring.

\section{CONCLUSION}

In this study, the microbiological analysis revealed poor raw cow's milk quality sold through street trading. Therefore, raw milk that is intended for direct consumption cannot be considered microbiologically safe. Currently, in Morocco, there is no legislative requirement regarding the selling of raw milk and dairy products by street traders. However, the microbiological quality of raw milk is believed to be influenced by handling practices during milking, hygiene and sanitation personnel, storage, transport equipment, healthy cows, water quality and seasonal variation.

Some measures may be applied to evaluate the microbiological quality of raw milk. These include the establishment of milk hygiene standards, information to the producers, street trading and consumers, and action to strengthen the regulatory framework of the activity of street traders.

\section{ACKNOWLEDGEMENTS}

We thank the public health department of Fez Meknes region for helpful collaboration.

\section{REFERENCES}

Barkema, H. W., Schukken, Y. H. and Zadoks, R. N. (2006). The role of cow, pathogen and treatment regimen in the therapeutic success of bovine Staphylococcus aureus mastitis. Journal of Dairy Science 89, 1877-1895.

Bouymajane, A., Filali, F. R., Oulghazi, S., Ed-dra, A., Benhallam, F., El Allaoui, A., Anissi, J., Sendide, K., Ouhmidou, O., Moumni, M. (2018). Occurrence, molecular and antimicrobial resistance of Enterococcus spp. isolated from raw cow's milk trade by street trading in Meknes city, Morocco. Germs 8, 77.

Brooks, J. C., Martinez, B., Stratton, J. Bianchini, A., Krokstrom, R. and Hutkins, R. (2012). Survey of raw milk cheeses for microbiological quality and prevalence of foodborne pathogens. Food Microbiology 31, 154-158. 
Centre Anti Poison et de Pharmacovigilance du Maroc (CAPM) (2015). Review of toxicology. Morocco.

Chrstine, B., Özgun C. O. U., Pablo, E. H., Dzung, B. D. and Gaspar, P. M. (2017). A method to assess bacteriocin effects on the gut microbiota of mice. Journal of Visualized Experiments 125, 1-10.

D'Amico, D. J. and Donnelly, C. W. (2010). Microbiological quality of raw milk used for small-scale artisan cheese production in Vermont: Effect of farm characteristics and practices. Journal of Dairy Science 93,134-147.

Ed-Dra, A., Filali, F. R., El Allaoui, A., Sfendla, A. (2017c). Occurrence of Clostridium perfringens in sausages sold in Meknes city, Morocco. Open Veterinary Journal 7, 323-327.

Ed-dra, A., Filali, F. R., Karraouan, B., El Allaoui, A., Aboulkacem, A., Bouchrif, B. (2017b). Prevalence, molecular and antimicrobial resistance of Salmonella isolated from sausages in Meknes, Morocco. Microbial pathogenesis, 105, 340-345.

Ed-Dra, A., Rhazi Filali, F., El Allaoui, A., Aboulkacem, A. (2017a). Factors influencing the bacteriological quality of sausages sold in Meknes city, Morocco. International Food Research Journal 24, 933-938.

Fook, Y. C., Aminah, A., Mohd K. A. (2004). Bacteriological quality and safety of raw milk in Malaysian. Food Microbiology 21, 535-541.

Ghafir, Y., Dierick, K. and Zutter, L. D. E. (2008). Hygiene indicator microorganisms for selected pathogens one beef, pork, and poultry meats in Belgium. Journal of Food Protection 71, 35-45.

Griffiths, M. W. (2010). The microbiological safety of raw milk. In: Improving the Safety and Quality of Milk. Griffiths, M. W. (ed.). Woodhead Publishing Limited, Cambridge, UK. pp. 27-63.

Gurmu, E. B., Hazarika, R. A., Borah, A. and Barua, A. G. (2013). Prevalence of enterotoxigenic Clostridium perfringens in foods of animal origin, Guwahati.India. Journal of Environmental and Occupational Science 2, 45-50.

Hadrya, F., El Ouardib, A., Hamia,H., Soulaymania, A. and Senouci, S. (2012). Microbiological quality assessment of dairy products marketed in Rabat-SaléZemmour-Zaer region in Morocco. Cahiers de nutrition et de diététique 47, 303-307.

Hervieu, B. (2007). The milk and milk product in sector of Morocco. In: Identity and Quality of Mediterranean foodstuffs. Hervieu, B. (ed.). Presses de la Fondation Nationale des Sciences Politiques (OFCE), France. pp. 279-297.

Hill, B., Smythe, B., Lindsay, D. and Shepherd, J. (2012). Microbiology of raw milk in New Zealand. International Journal of Food Microbiology 157, 305308.

Ibtissam, E. M. E and Mahboba, I. A. A. (2007). The hygienic quality of raw milk produced by some dairy farms in Khartoum State, Sudan. Research Journal of Microbiology 2, 988-991.
Ismaili, M. A., Bouchta, S., Mohamed, Z., Abed, H. and Raghia, E. (2016) Composition and microbial quality of raw camel milk produced in Morocco. Journal of the Saudi Society of Agricultural Sciences 18(1), 17-21.

ISO/FDIS.15214. (1998). Microbiology of food and animals feeding stuffs-horizontal method for the enumeration of mesophilic lactic acid bacteria. France. pp.1-8.

Koushki, M., Koohy. K. P., Aziz Khani, M and Hadinia, N. (2016). Microbiological quality of pasteurized milk on expiration date in Tehran, Iran. Journal of Dairy Science 99,1-6.

Lan, X. Y., Zhao, S.G., Zheng, N., Li, S.L., Zhang, Y. D, Liu, H. M., J. Q. and Wang, J. Q. (2017). Short communication: Microbiological quality of raw cow milk and its association with herd management practices in Northern China. Journal of Dairy Science 6, 42944299.

Lejeune, J. T., and Rajala-schultz, J. (2009). Unpasteurized milk: A continued public Health threat. Food Safety 48, 93-95.

Liu, D. (2008). Handbook of Listeria monocytogenes. Taylor \& Francis Group, New York. pp.16-17

Maha, A. I., Bouchta. S., Mohamed, Z., Abed, H. and Raghia, E. (2016). Composition and microbial quality of raw camel milk produced in Morocco. Journal of the Saudi Society of Agricultural Sciences. https://doi.org/10.1016/j.jssas.2016.12.001

Mallet, A., Guéguen, M., Kauffmann, F., Chesneau, C., Sesboué, A. and Desmasures, N. (2012). Quantitative and qualitative microbial analysis of raw milk reveals substantial diversity influenced by herd management practices. International Dairy Journal 27, 13-21.

Mcclane, B. A. (2001). The complex interactions between Clostridium perfringens enterotoxin and epithelial tight junctions. Toxicon 39, 1781-1791.

Millogo, V. (2009). Milk production of hand-milked dairy cattle in Burkina Faso. Doctoral Thesis. Faculty of Veterinary Medicine and Animal Science, Uppsala.

Ministry of Agriculture (2004). Arrêté conjoint du ministre de l'agriculture et du développement rural, du ministre de la santé et du ministre de l'industrie, du commerce et des télécommunications $n^{\circ} 624-04$ du 17 safar 1425 (8 avril 2004) relatif aux normes microbiologiques auxquelles doive nt répondre les denrées animales ou d'origine animale. Le Ministre De l'Agriculture Et Du Developpement Rural, Maroc.

Özer, B. and Yaman, H. (2014). Microbiology of liquid milk. In: Encyclopedia of Food Microbiology (2 $2^{\text {nd }}$ edn). Batt, C. A. and Tortorello, M. L. (eds.). Academic Press, USA. pp.721-727.

Paszkiewicz, W., Tatara, M.R., Brodzki, P., and Bełkot. Z (2015). Microbiological quality of milk sold directly from producers to consumers. Journal of Dairy Science 98, 1-8.

Piret. K., Toomas. K., Mati. R., Kadrin. M. and Arvo, V. (2015). Quality of raw milk intended for direct consumption in Estonia. Food Control 51, 135-139. 
Malays. J. Microbiol. Vol 15(6) 2019, pp. 425-431

DOI: http://dx.doi.org/10.21161/mjm.180079

Pougheon. S and Goursaud, J. (2001). Le lait : caractéristiques physicochimiques, nutrition et santé. Tec. Doc. France. pp. 6-566.

Rowayda, O., Marwa, K., Khalifa, A.T. and AlAshmawy. M. (2015). Prevalence and Antimicrobial Resistance of Clostridium perfringens in milk and dairy products. World Journal of Dairy \& Food Sciences 10,41-146.

Schaarschmidt, S., Spradau, F., Mank, H., Banach, J.L., van der Fels-Klerx, H. J. Petra Hiller, P., Appel, B., Braunig, J., Wichmann-Schauer, H. and Mader, A. (2016). Public and private standards for dried culinary herbs and spices d Part II: Production and product standards for ensuring microbiological safety. Food Control 70, 360-370.

Schechter, M. (2009). Encyclopedia of microbiology. Elsevier. pp.34-43

Smigic, N., Djekic, I., Tomasevic, I., Miocinovic, J., Gvozdenovic, R. (2012). The implication of food safety measures on the microbiological quality of raw and pasteurized milk. Food Control 25,728-731.

Umu, O. C. O., Rudi, K. and Diep, D. B. (2017). Modulation of the gut microbiota by prebiotic fibers and bacteriocins. Microbial Ecology in Health and Disease 28, 1-11.

Wendie, L. C., Sabine, C., Georges, D., Jan D. B. Koen, D. Katelijne, D., Lieven, D. Z., André, H., Hein, I., Pierre, T., Van., Yvan, V. and Lieve, $H$. (2013). Raw or heated cow milk consumption: Review of risks and benefits. Food Contro/ 31, 251-262.

World Health Organization (WHO) (2015). Food safety and foodborne diseases. Geneva.

Yoon. Y, Lee, S., and Choi, K. (2016). Microbial benefits and risks of raw milk cheese. Food Control 63, 201215. 